\title{
The Extent of Sunlight Penetration Performance on Traditional Style's Apartment Façade in Putrajaya, Malaysia
}

\author{
Ahmad Sanusi Hassan ${ }^{1} \&$ Yasser Arab ${ }^{1}$ \\ ${ }^{1}$ School of Housing, Building and Planning, Universiti Sains Malaysia, 11800 USM, Penang, Malaysia \\ Correspondence: Ahmad Sanusi Hassan, School of Housing, Building and Planning, Universiti Sains Malaysia, \\ 11800 USM, Penang, Malaysia. Tel: 60-19-506-8260. E-mail: sanusi.usm@gmail.com
}

Received: July 10, 2014

Accepted: July 15, $2014 \quad$ Online Published: August 27, 2014

doi:10.5539/mas.v8n5p132

URL: http://dx.doi.org/10.5539/mas.v8n5p132

The research is financed by Universiti Sains Malaysia.

\begin{abstract}
In this study the analysis is to measure the performance on the extent of sunlight penetration on front apartment facades. The apartments are located in Putrajaya, Malaysia. Putrajaya is the administrative city for the federal government, and it is considered the latest new city in Malaysia with postmodern style buildings which exhibit a range of complex geometric elements blending with colonial, modern and traditional architectural style. The scope of this study is to measure the extent of sunlight penetration on the apartment facades. Two front facades of the apartments were selected in the case studies using computer simulation for the analysis. The selected case studies are sixteen stories apartment located in Precinct 17 and seventeen stories apartment located in Precinct 18. SunTool software is used in the survey to calculate the extent of sunlight penetration. The survey will be conducted at a position when the sun path is perpendicular to the house façade. This analysis will compare results of the computer simulations of these two apartments in relation to the facade design of the architectural elements for shading devices. This study finds that the more the application is the traditional shading elements, the more is the shading performance on the façade walls. However this study also finds that traditional shading elements are designed only to block sunlight from horizontal angle of the sun position. They are not designed to obstruct sunlight from vertical angle of the sun position.
\end{abstract}

Keywords: sunlight, traditional shading elements, penetration, apartment, Malaysia

\section{Introduction}

\subsection{Problem of Direct Sunlight Penetration}

This study highlights problem of direct sunlight penetration to the interior area of apartment building and solar radiation on the apartment facade in tropical countries like Malaysia. Poor design integrated with shading elements which causes poor shading performance is the primary causes of the problem as the hypothesis of this study. This problem creates heat gain to the indoor area which causes low level on human comfort factor to the house occupants. The study on high rise apartment design is important because the building façade has a larger area with a tendency of exposure to direct sunlight compared to the building façade of low rise building (Ismail, 2002). As a result, design with excellent shading elements on the apartment façades is very critical. It is the objective in this study to verify the problem scientifically to dictate this design faults by measuring the extent of sunlight penetration on the apartment façade. Results of this study can be used as a guide for architects and those involved in the building industry to refer as issues to overcome solar radiation in apartment façade design. This reference provides awareness and guidelines for passive design with efficient usages of shading elements to avoid solar radiations in the tropical countries such as Malaysia (Bakhlah \& Hassan, 2012).

\subsection{Importance of the Problem}

The measurement will be calculated using either manual or computer simulation. This study is limited to the apartment design in Putrajaya which is the latest new town built in Malaysia with post modern building styles. It epitomizes the present and future direction of housing industry in Malaysia. One of the popular post modern styles is integration of traditional Malay architectural style. It is the aim of this study to measure effectiveness of the integration of traditional Malay shading elements in post modern apartment which are roof overhang, 
recessed wall, attached roof and balcony or corridor. House facade exposed to direct sunlight causes problem of solar radiation. The sun energy will radiate the heat from outside wall transmitted into the interior of the house (Hassan \& Ramli, 2010) (Feriadi \& Nyuk, 2004). It generates extra heat gains inside the house which causes warm temperature to the indoor area; as a result, it creates uncomfortable thermal condition to the occupants. A report by Centre for Environment, Technology and Development, Malaysia (CETDEM) (2005) on Malaysian Urban Household Energy Consumption Patterns stated that electricity consumption on air-conditioning and fan for cooling purpose is the highest with $32.4 \%$ of the total electric bill, which indicate problem in indoor heat gains due to unnecessary direct sunlight exposure to the houses in Malaysia. A study on high rise apartment is crucial as apartments in Putrajaya are the most popular house types which represent $73 \%$ of the total unit houses (Department of Statistics, Malaysia, 2010).

\subsection{Relevant Scholarship}

There are many previous related studies on solar radiation in building design. However, there is no scientific study specifically referring to the discussion on traditional Malay shading elements on contemporary apartment design. There are studies by several scholars concerning thermal comfort factors due to problems of indoor heat gains in Malaysia. Early study by Victor Olgyay had argued on the importance of solar control and the integration shading devices in modern building design with reference to the climate of the region, which guides the architects to understand on the passive heating and cooling system in architectural design. One of the recent studies was by Ismail and Idris (2002), and Lim, Ahmad and Ossen (2013) issues on heat gains due to exposure of modern and contemporary high rise building facades to direct sunlight. The other study was by Abdul Rahman (1995) and Omer (2008) on housing design related to thermal comfort with integration of passive design solution to tackle solar radiation.

\subsection{Research Design}

With reference to the importance of the study in the earlier discussion, this study creates a research design leading to provide answers based on the result of analysis on direct sunlight penetration to indoor area from the apartment façade in Putrajaya, Malaysia. SunTool software will be use in the survey to simulate the results, showing the extent of sunlight penetration values the at the selected sun positions. The software provides reliable data used in a study. It is computer software which provides performance data the same as the data provided by manual calculation in measuring shading performance of the building facade using solar chart superimposed by shadow angle protractor as illustrated in Figure 1. With the results of analysis as performance data, this study can verify the strengths and weaknesses of the traditional shading elements integrated in the apartment façade design. Among the research questions are as follows:

a) Are apartments designed with traditional Malay style has a facade with good shading performance?

b) To what extent does the performance of traditional shading elements in blocking direct sunlight on the apartment facade?

c) What are the types of traditional shading elements which provide excellent shade on the apartment facade?

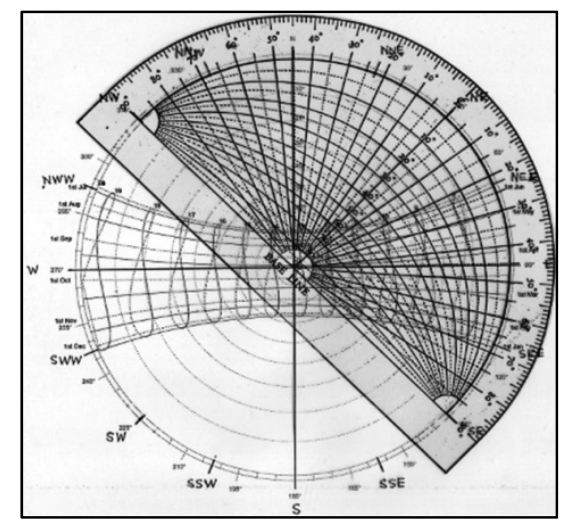

Figure 1. Solar chart superimposed by shadow angle protractor

\section{Literature Review}

One of the popular post modern style in apartment design in Putrajaya, Malaysia is an integration of traditional 
Malay architectural style. According to Hassan (2004), many traditional buildings have a roof system made from two different roof slopes. The upper pitch roof is relatively steep about 45-55 degree compared to the lower pitch roof (also known as 'attached roof'), which has about 25 degrees slope. The two pitches are merged to form two different roofs slopes under one roofing system. This type of roofing system is the most commonly constructed for the core house (rumah ibu) normally attached with balcony known as 'anjung'. Based on Khan (1981), the application of pitch roof in building construction in Nusantara Region is a logical choice in hot wet climatic conditions. The steep pitch, permits rapid removal of rain water and creates a high sloping ceiling ideal for inducing air movement, ventilation and escape of hot air, thus bringing in comfort (Hassan \& Ku Hassan, 2001).

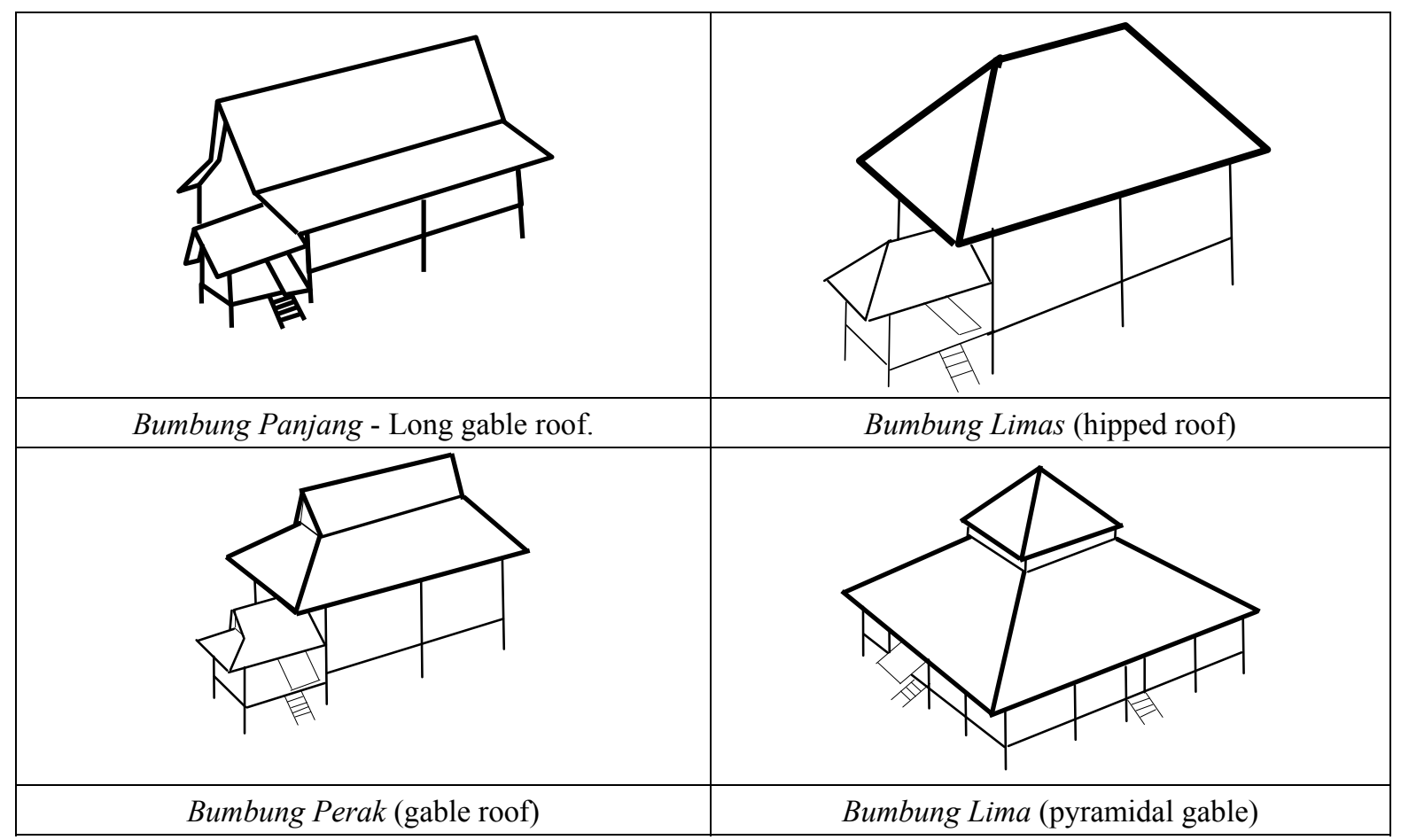

Figure 2. Traditional roof types

Long roof (Bumbung Panjang) building is characterised by a long gable roof (Figure 2). Its simple construction accounts for its popularity and is also the most highly developed of the various building types. It has a system which allows extensions and addition of many type and variation. Long roof building type is the simplest of the four building forms. It has a simple gable roof, supported by kingposts. The most common roofing material used for the bumbung panjang is the attap. Attap is thatch made from nipah and other palm trees found in the local natural vegetation. Limas Roof (Bumbung Limas) is characterised by a hipped roof which is believed to be influenced by colonial roof form. The floor plan is almost square in shape and the common types of roofing materials are either clay tiles or asbestos sheet. An urban family as it allows the use of modern furniture which requires higher headroom. Limas roof form is not originated from Nusantara Region but developed through foreign influences such as the colonial Dutch and British building forms during their period in the country.

Perak Roof (Bumbung Perak) is believed to be copied from Dutch building forms in the colonial period (Figure 1). The pointed high pitch roof uses a combination of attap (nipah roof), zinc and other modern roofing materials to allow for the more elaborate roof construction here. The ridge is straight. The centre of the roof is covered with attap. This technique ensures that the building does not over heat during the day and has the ventilating properties of the attap. Because the edges of the roof are protected by the metal, the roof is last longer. Lima Roof (Bumbung Lima) is commonly used for mosque and Surau (building not conducted Friday Prayer). It is a square base in plan with recessed wall for corridor (also known as 'serambi') and usually raised several foot above the ground. The roof is a two and three-tiered pyramidal form (pyramid roof with two tiers attached roof system. The tiers of the roof are meant for ventilation purposes in the hot humid climate of Nusantara Region. The top most roofs are lifted high enough to allow the presence of clerestory windows. It is tiered with attached roof and made of more permanent materials like tiles or shingles rather than attap. Thus the number of tiers is related to the size of the mosque's plan. 


\section{Case Study}

Two apartment buildings with traditional architectural style were selected as the case studies. This research will compare and analyse the extent of sunlight penetrations and the effectiveness of the existing shading devices on apartment façades with a design of the traditional architectural style. Both apartment locations are in Putrajaya, the administrative city for the federal government of Malaysia. The new town is the latest city built in Malaysia (Hassan, 2005; Hassan, 1999). The first case study (also marked as Traditional 1) is an apartments building consists of sixteen stories located in Precinct 16 (Figure 3). It has Perak roof type. The second case study (Figure 4) (also marked as Traditional 2) is a seventeen storey apartments located nearby artificial lake in Precinct 18. It has long roof type. Since there are many house units in one apartment block, this study has selected facades the most top floor unit for the simulation and analysis.

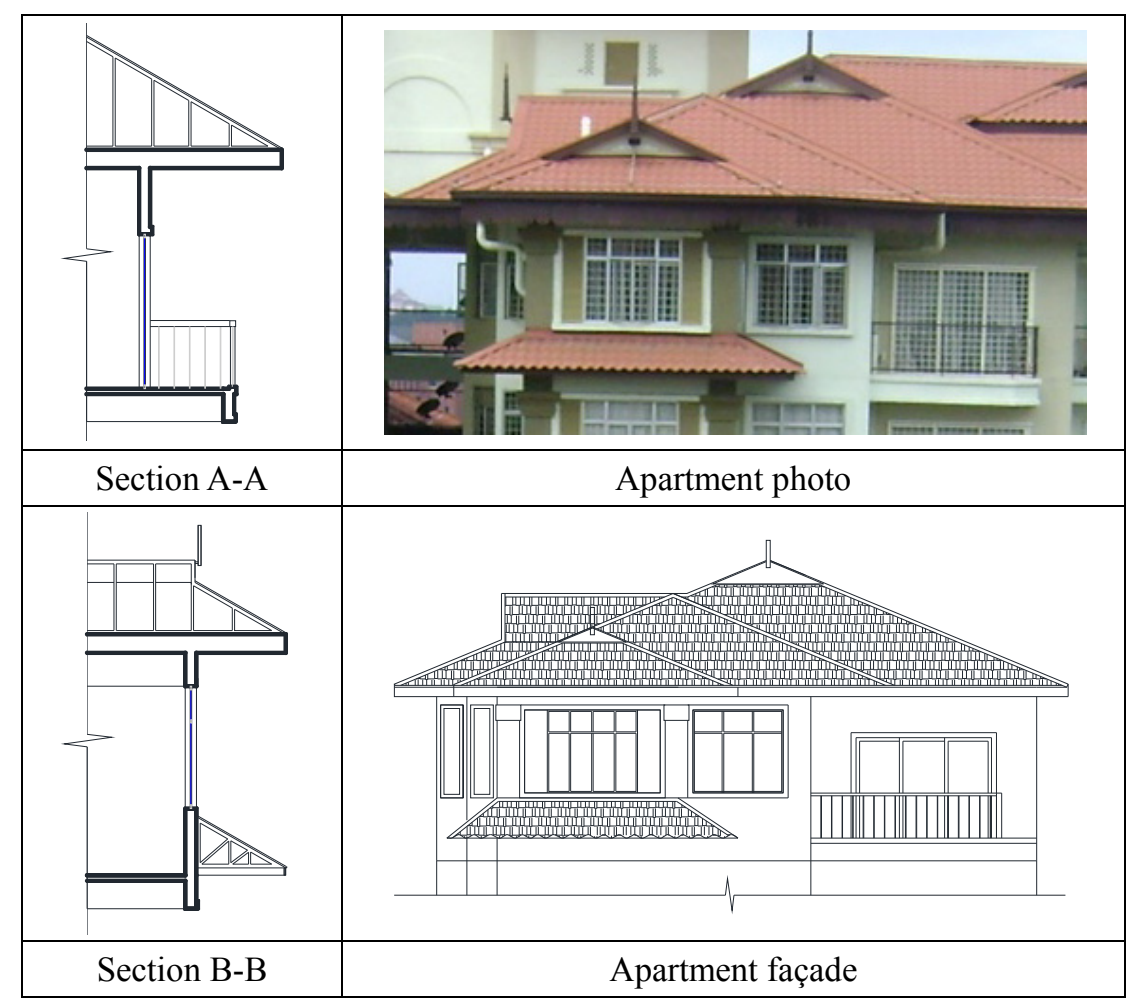

Figure 3 . The first case study apartment

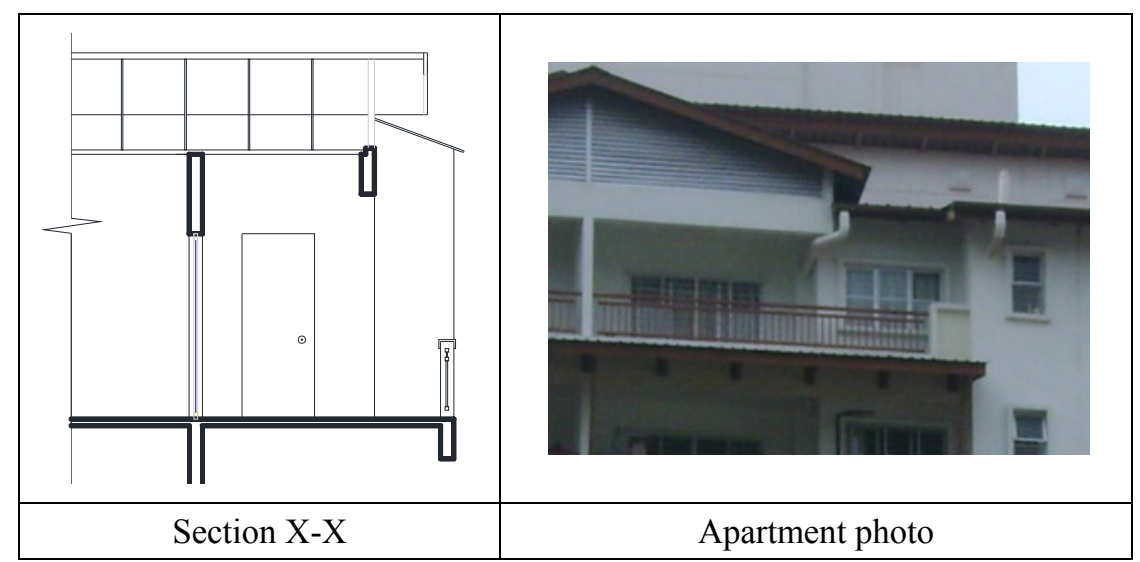




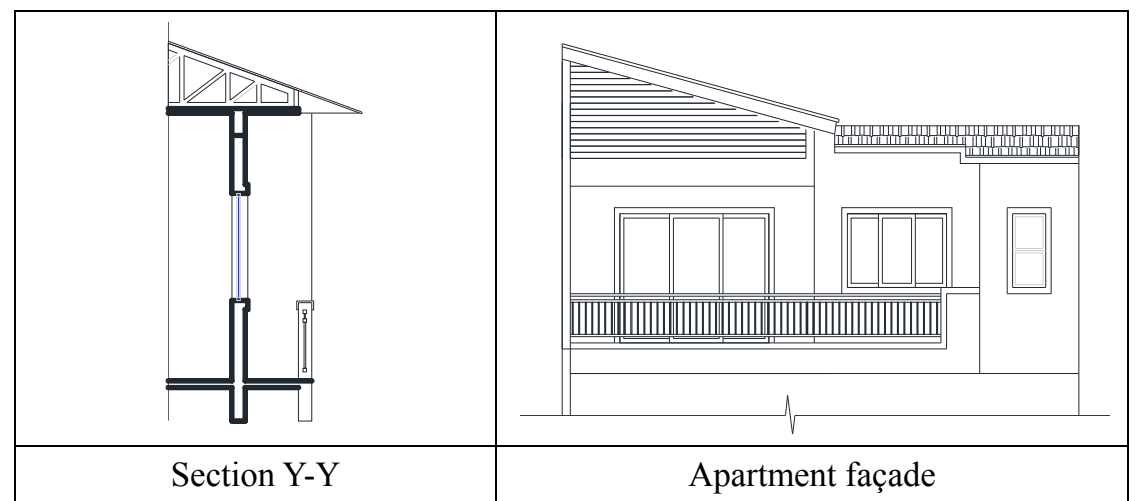

Figure 4. The second case study apartment

\section{Methods}

The simulation will be done using SunTool software to calculate the extent of sunlight penetration and the sunlight shading. This study aims to get the results of the extent of sunlight penetration when the building facade exposes to the sunlight at the maximum level at a day time; by doing the simulation when the sunlight are perpendicular to the house facade (east facade during morning hours and west facade during evening hours of simulation), then the survey will be able to discuss the efficiency of facade's shading design (Mazloomi, Hassan, Bagherpour, \& Ismail, 2010). In order to get the results at the maximum exposure level, the study will be limited to the changing of the sun path to get the perpendicular of the sunlight to the east $\left(90^{\circ}\right)$ and west $\left(270^{\circ}\right)$ Table 1 and Figure (5), and also the other limitation is that there are at certain times and dates that the sun path's azimuth is not possible to have perfectly at $90^{\circ}$ (Hassan \& Arab, 2013; Arab \& Hassan, 2012). In these cases, the closest azimuths nearest to $90^{\circ}$ will be used when the simulation is made from 8:00 am to 7:00 pm, which are listed in Table 1. It is important for a tropical country like Malaysia where the duration of daytime and night time is almost the same throughout a year.

Table 1. Time, date and azimuth of the sun when the sunlight extent penetration of façade was calculated for cases in Malaysia

\begin{tabular}{cccccccc}
\hline Orientation & Time & Date & Azimuth & Orientation & Time & Date & Azimuth \\
\hline & $7 \mathrm{am}$ & 23 March & $90^{\circ}$ & $1 \mathrm{pm}$ & 16 September & $90.5^{\circ}$ \\
& $8 \mathrm{am}$ & $25 \mathrm{March}$ & $90^{\circ}$ & $2 \mathrm{pm}$ & 29 March & $89.8^{\circ}$ \\
\multirow{5}{*}{ East $90^{\circ}$} & $9 \mathrm{am}$ & 27 March & $89.8^{\circ}$ & West $270^{\circ}$ & $\mathrm{pm}$ & 18 September & $89.8^{\circ}$ \\
& $10 \mathrm{am}$ & $28 \mathrm{March}$ & $90.1^{\circ}$ & & $4 \mathrm{pm}$ & 26 March & $89.9^{\circ}$ \\
& $11 \mathrm{am}$ & 29 March & $90^{\circ}$ & $5 \mathrm{pm}$ & 24 March & $89.9^{\circ}$ \\
& $12 \mathrm{pm}$ & 29 March & $92.2^{\circ}$ & $6 \mathrm{pm}$ & 22 March & $89.9^{\circ}$ \\
\hline
\end{tabular}




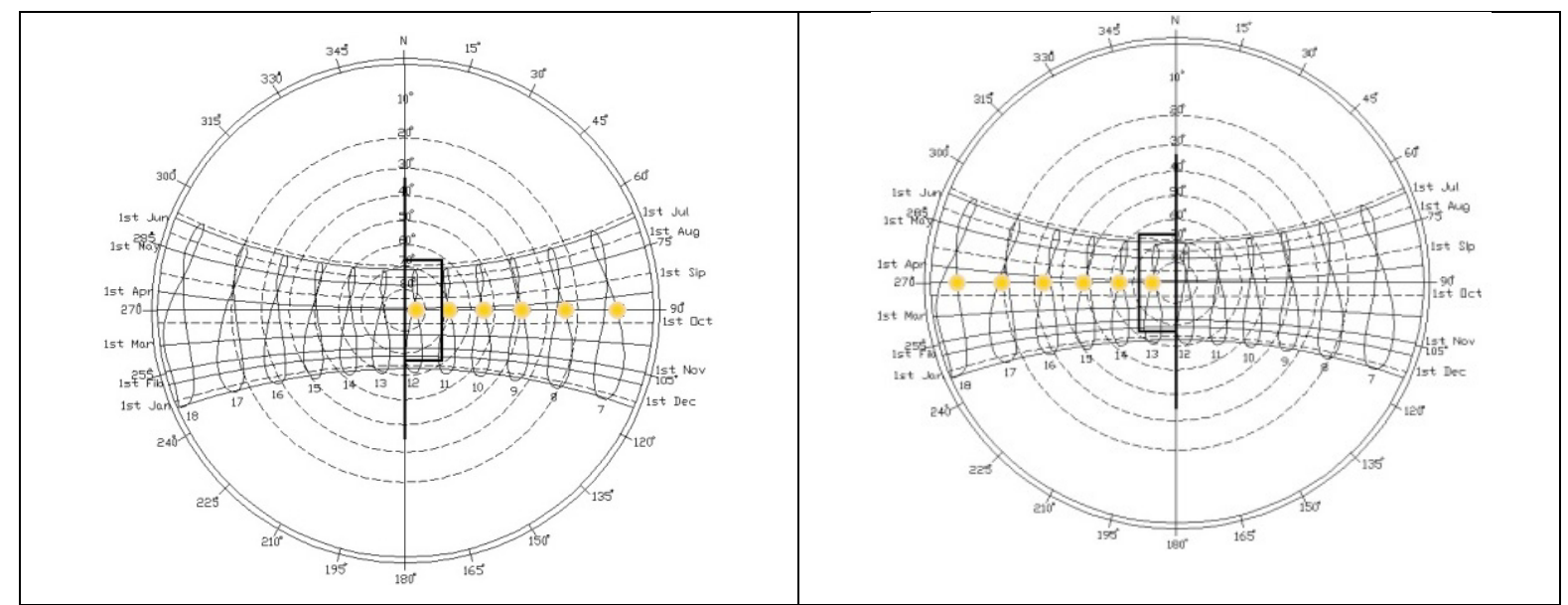

Figure 5. Sun path diagram shows the position of the sun perpendicular to the house facade from $7 \mathrm{am}$ to $12 \mathrm{pm}$ at orientation of $90^{\circ}$ (left) and from $1 \mathrm{pm}$ to $6 \mathrm{pm}$ at orientation of $270^{\circ}$ (right). Source: SunTool Software

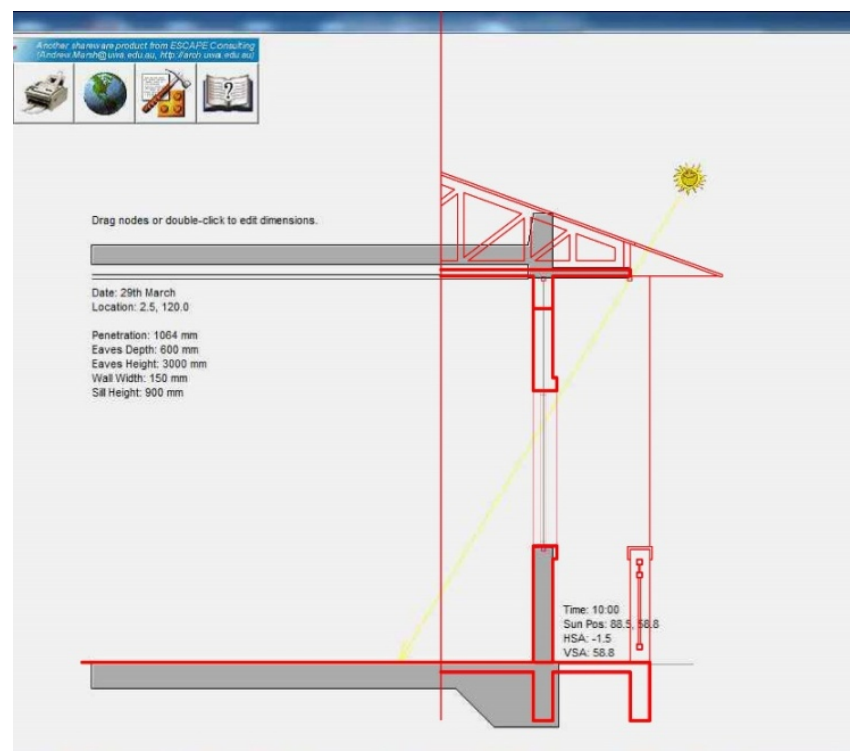

Figure 6. SunTool software (window section)

In order to get the correct position and orientation, all data about the location, time, date and orientation will be keyed into the SunTool software to do the simulation and calculate the percentage of facade's shading area and the extent of sunlight penetration (Figure 6). And then the facade's dimensions such as depth of exterior shading device, height, wall's width and sill height will be keyed in the SunTool software. After drawing the facade and entering all required data, the software will be able to do the simulation and provides the facade shading area and the extent of sunlight penetration inside the house for the analysis. The extent of sunlight penetration inside the room will be measured using the same software (The SunTool) as shown in Figure 7. However, if the overhang shading device is longer than the upper window wall (Figure 8), the second line must be drawn parallel to sun beam of the upper window wall. The second line represents the actual extent of the sunlight penetration. This condition commonly occurs in the early morning and late evening due to low sun angle in the sky. The calculation will be as follow (Hassan \& Bakhlah, 2013):

Penetration $=$ Extent of the Sunlight Penetration calculated by the SunTool software $(\mathrm{mm})-$ Distance between two lines $(\mathrm{mm})$ 


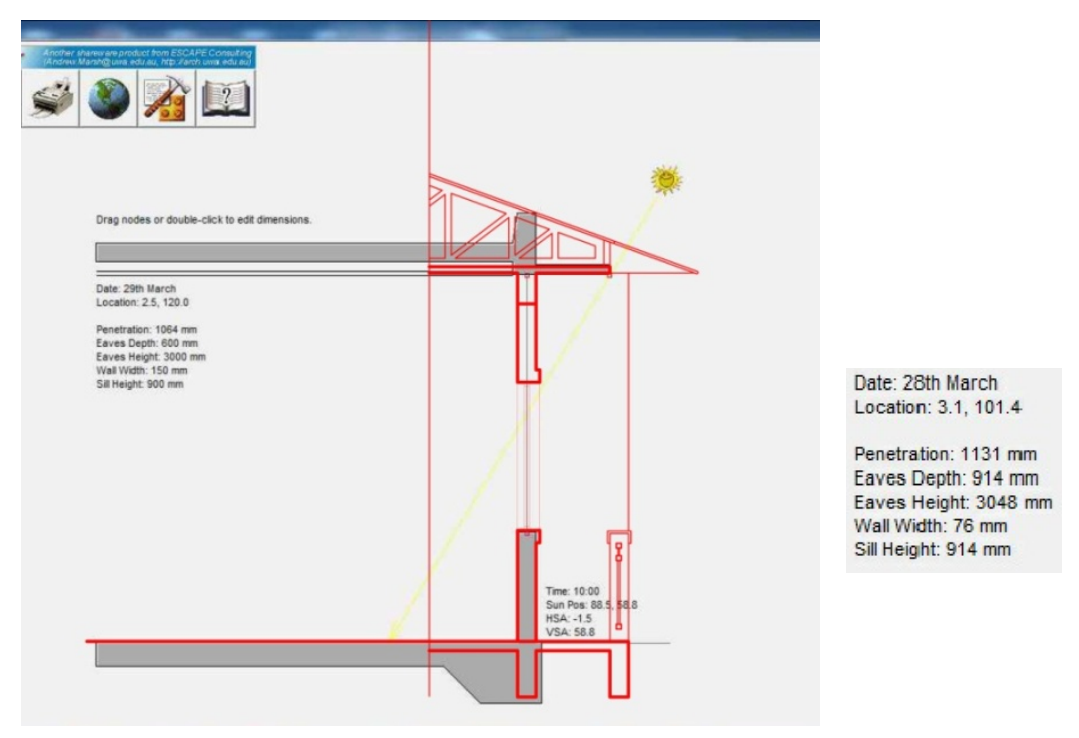

Figure 7. The extent of sunlight penetration given by the SunTool software

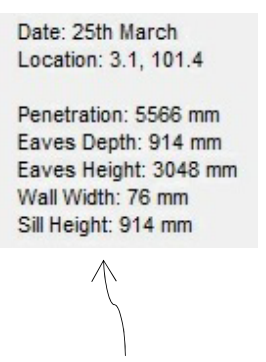

Penetration given by the software

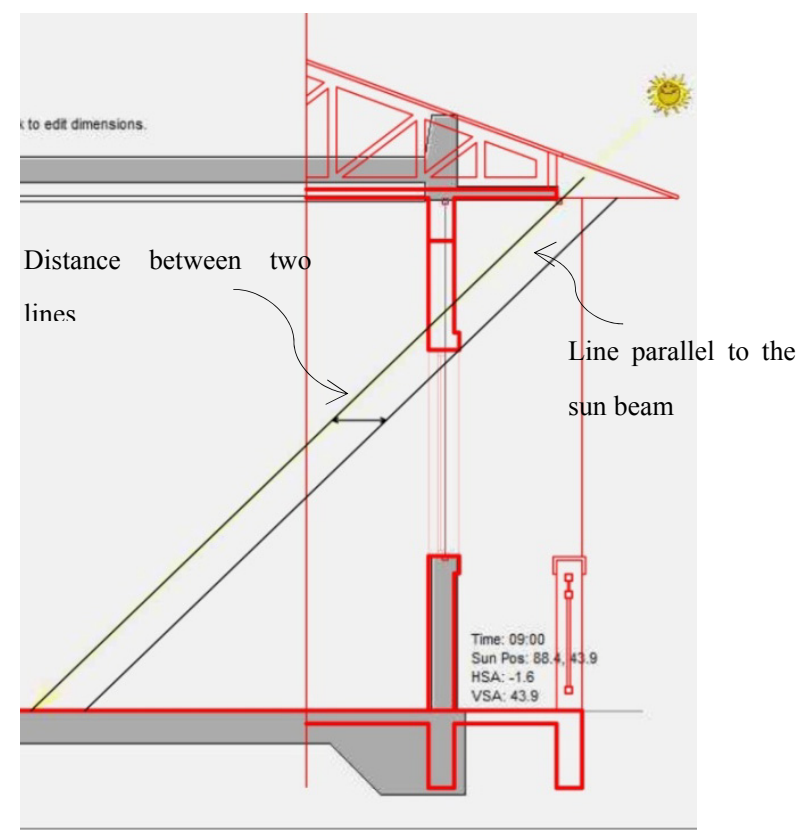

Figure 8. The extent of sunlight penetration calculation when the overhang shading device blocking the sunlight higher than the upper window wall

\section{Results of Analysis}

This study analysis compares results generated by the computer simulation on the extent of sunlight penetrations of the most top floor unit's facade of the two traditional style apartments located in Putrajaya, Malaysia. The comparison will be window section between Section A-A from the first case study and Section Y-Y from the second case study. The other comparison is between Section B-B and X-X (door section). Table (2) and Figures ( 9 and 10) show the comparative data on results of the extent of the sunlight penetration of Window Section A-A and $\mathrm{Y}-\mathrm{Y}$ and Door Section B-B and X-X of the first and second case study. 
Table 2. The extent of sunlight penetration of the first and second case study

\begin{tabular}{cllll}
\hline \multicolumn{5}{c}{ Window Section } \\
Time & Traditional 1 & $\begin{array}{c}\text { Traditional 2 } \\
\text { Section Y-Y }\end{array}$ & Traditional 1 & Door Section \\
Section B-B & Traditional 2 \\
Section X-X
\end{tabular}

The first comparison is on window section. The extent of sunlight penetration as shown in Figure 9 for Section A-A was $14620 \mathrm{~mm}$ at 8:00 am in the morning (one hour after the sunrise), and then it had decreased gradually from $5103 \mathrm{~mm}(9: 00 \mathrm{am})$ and $2213 \mathrm{~mm}(10: 00 \mathrm{am})$ to reach $738 \mathrm{~mm}$ at 11:00 am. From 12:00 pm until 3:00 pm the façade had excellent shading performance without sunlight penetration. The overhang roof design was excellent because it was able to block the sunlight penetration into the building during the period from 11:00 am to 3:00 pm where heat level from sunlight was high. However during the evening hours, the extent of sunlight penetration had steady increases from $1431 \mathrm{~mm}$ at 4:00 pm and $2925 \mathrm{~mm}$ at 5:00 pm to $6806 \mathrm{~mm}$ at 6:00 pm. This penetration had caused heat gains to the indoor area of the apartment unit. The maximum sunlight extent penetrated at the last hour of simulation $(7: 00 \mathrm{pm})$ with $27919 \mathrm{~mm}$ when the sunbeams were almost perpendicular to the west façade.

This analysis finds that the second case study had slightly better shading performance than the first case study on the extent of sunlight penetration during morning hours from 8:00 am to 12:00 pm and late evening hours from 6:00 to 7:00 pm. However during evening hours from 3:00 to 5:00 pm, the results on the extent of sunlight penetration on the apartment facade had slightly poorer performance than the first case study. The sunlight penetration at 8:00 am was $11988 \mathrm{~mm}$ and then it had a gradual decline from 4352, 2338 and 1298 at 9:00, 10:00 and 11:00 am respectively to $328 \mathrm{~mm}$ at12:00 pm. The result shows that no sunlight penetration was from 1:00 to 2:00 pm. However, the second case study had a steady increases on the sunlight penetration starting from $660 \mathrm{~mm}$ at $3: 00 \mathrm{pm}, 1981 \mathrm{~mm}$ at $4: 00 \mathrm{pm}$ and $3009 \mathrm{~mm}$ at 5:00 pm to $4772 \mathrm{~mm}$ at 6:00 pm. The longest extent was at 7:00 pm with $24280 \mathrm{~mm}$ due to the sumbeam almost perpendicular to the house façade during the sunset. 


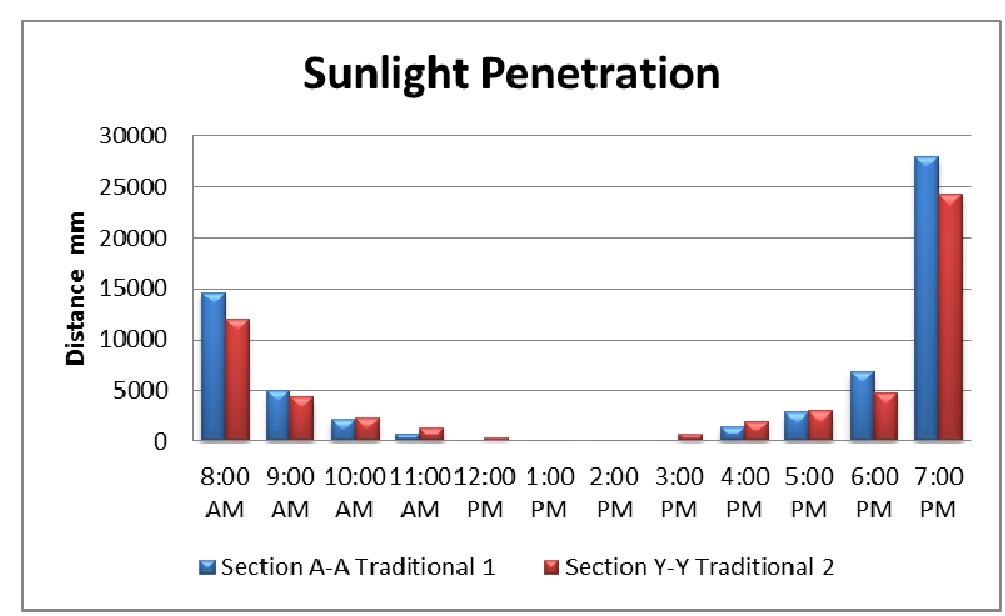

Figure 9. The extent of sunlight penetration of Section A-A and Y-Y

The second comparison on this study is to compare the extent of sunlight penetrations of the door sections at both case studies with reference to results of the simulation on Section B-B and X-X (Figure 10). Table 2 shows that the first case study had slightly poorer results of shading performance than the second case study except at 8:00 am and 7:00 pm. The first case study had $11842 \mathrm{~mm}$ extent of the sunlight penetration compared to the second case study with $12073 \mathrm{~mm}$ about one hour after the sunrise. From 9:00 to 11:00 am, the extent of sunlight penetration had steady decreased from $4347 \mathrm{~mm}$ at 9:00 am and $1613 \mathrm{~mm}$ at 10:00 am to $138 \mathrm{~mm}$ at 11:00 am. The analysis finds that no sunlight penetration from 12:00 pm to 3:00 pm. However, the sunlight penetration had occurred at 4:00 pm with $831 \mathrm{~mm}$ and later had gradual increases from $2325 \mathrm{~mm}$ at 5:00 and 5540 mm at 6:00 pm with to the maximum extent of sunlight from the west façade with $22774 \mathrm{~mm}$ at 7:00 pm (about sunset time) during the simulation. The second case study had started with $12073 \mathrm{~mm}$ at 8:00 am and later had a steady decline to $3392 \mathrm{~mm}$ at 9:00 am and $912 \mathrm{~mm}$ at 10:00am. There was no sunlight penetration occurred from 11:00 am to 3:00 pm which means that the indoor area were free from sunlight exposure during these 4 hours. At 4:00 pm, the indoor area received a small amount of sunlight penetration with only $36 \mathrm{~mm}$, and later it had the sunlight penetration with gradual incline from $1535 \mathrm{~mm}$ at 5:00 pm to $4890 \mathrm{~mm}$ at 6:00 pm. Due to then sunbeam at almost perpendicular to house façade at 7:00 pm (sunset), the sunlight had deepest penetration to the indoor area with $27121 \mathrm{~mm}$.

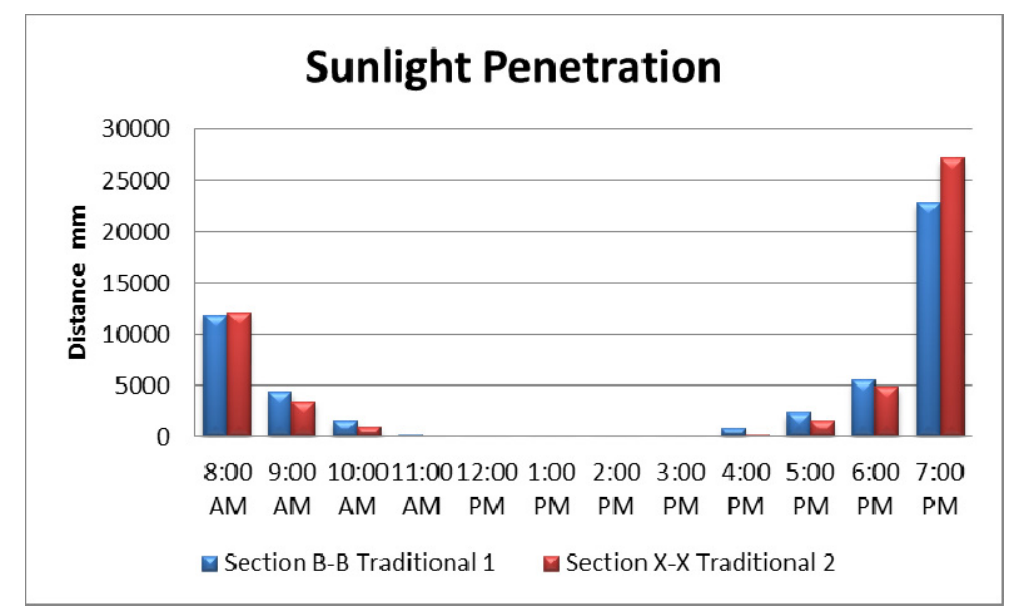

Figure 10. The extent of sunlight penetration of Section B-B and X-X

\section{Discussion}

The findings from the results of analysis are discussed as follows:

1. This study finds that the early morning hours show sunlight penetration between $10000 \mathrm{~mm}$ and $15000 \mathrm{~mm}$ 
in both of window and door sections at both case studies. However, these extents of sunlight penetration are not critical as they occurred about one hour after sunrise time and during early morning.

2. Sunlight penetration to the indoor area from sunrise time from to 10:00 am is not acute because it is during early morning hours which are necessary for the human skin exposure to sunlight for gaining Vitamin D formation on the skin tissue (Landry \& Breton, 2009).

3. The façade had satisfactory shading performance from 10:00 to 11:00 am. The longest extent of sunlight penetration ranging from 138 to $1298 \mathrm{~mm}$.

4. Both case studies have excellent shading performance from 12:00 am to 3:00 pm as most of the indoor areas did not have sunlight penetration. If they had, the sunlight penetration was very minimal.

5. All facades have poor shading performance from 4:00 to 5:00 pm. The range of the extent of sunlight penetration was from $831 \mathrm{~mm}$ at 4:00 pm except Door Section X-X in the Second Case Study, to $3009 \mathrm{~mm}$ at 5:00 pm. Having exposed to sunlight penetration during these hours is intolerable in passive design approach as it will generate a high heat gains from the harsh and warm sunlight, therefore creating solar radiation.

6. All the case studies had long extent of sunlight penetration at 6:00 pm. However the heat from sunlight is not as severe as the heat gained from 11:00 am to 5:00 pm.

7. Having sunlight penetration at 7:00 pm is not critical as it is sunset hour.

8. All the case studies applies traditional roof overhang concept in the design. In general, the second case study had better shading performance than the first case study. The recessed wall design in the case study 2 has given additional shading elements in blocking the sunlight. Recessed wall is another traditional shading element. In addition, the Door Sections had better shading performance than Window Sections. The Door Sections have integrated balcony or corridor element which blocks the sunlight.

9. Window Section in the first case study had the poorest performance. It only relies on its attached roof/roof overhang for the shading elements. Door Section in the second case study had the best performance with integration of roof overhang, balcony and recessed wall in the façade design.

The study finds that Door Section in the second case study has the best shading performance followed by Door Section in the first case study, Window Section in the second case study and Window Section in the first case study. Recessed wall, balcony, attached roof and roof overhang are a typical shading elements the traditional architectural style. They are very effective in preventing sunlight from getting penetration inside the house. This study finds that the more the application is the traditional shading elements, the more is the shading performance on the façade walls. However, traditional shading elements are not effective to block the sun angle especially from 3:00 to 6:00 pm which creating heat gains due to sunlight penetration to the indoor area for the both case studies. The reason is traditional shading elements are designed only to block sunlight from horizontal angle of the sun position. They are not designed to obstruct sunlight from vertical angle of the sun position. New shading devices for vertical sun angle must be integrated in the building façade. Maximum extent of sunlight penetration occurred during the sunrise (7:00-8:00 pm) and sunset (6:30-7:30 pm) hour because of the low angle of the sun position in the sky during these times (Landry \& Breton, 2009). However, the heat gain in indoor area due to solar radiation is tolerable because it generated by pleasant and light sunlight.

\section{Acknowledgments}

The authors would like to express appreciation for the financial support under Research University Grant by Universiti Sains Malaysia.

\section{References}

Abdul Rahman, A. M. (1995). Housing design in relation to environmental comfort. Build. Res. Inform., 23, 49-54. http://dx.doi.org/ 10.1080/09613219508727423

Arab, Y., \& Hassan, A. S. (2012). Daylighting analysis of pedentive dome's mosque design during summer solstice with case studies in Istanbul, Turkey. International Transaction Journal of Engineering, Management, \& Applied Sciences \& Technologies, 3(2), 167-183.

Bakhlah, M. S., \& Hassan, A. S. (2012). The study of air temperature when the sun path direction to Ka'abah: with a case study of Al-Malik Khalid Mosque, Malaysia. International Transaction Journal of Engineering, Management \& Applied Sciences \& Technologies, 3(2), 185-202.

CETDEM. (2005). Malaysian Urban Household Energy Consumption Patterns. Centre for Environment, Technology and Development, Malaysia. Petaling Jaya: CETDEM.

Department of Statistics Malaysia. (2010). Characteristics of Living Quarters 2010. Putrajaya: Department of 
Statistics Malaysia.

Feriadi, H., \& Nyuk, H. W. (2004). Thermal Comfort for Naturally Ventilated Apartments in Indonesia. Energy and Building, 36(7), 614-626. http://dx.doi.org/10.1016/j.enbuild.2004.01.011

Hassan, A. S. (2004). Issues in Sustainable Development of Architecture in Malaysia. Penang: Universiti Sains Malaysia Press.

Hassan, A. S. (1999). Putra Jaya: The Direction of Malaysian New Town. Proceedings of the 5th International Congress of Asian Planning Schools Association (APSA) (pp. 165-175). Seoul: Seoul National University.

Hassan, A. S. (2005). Konsep Rekabentuk Bandar di Semenanjung Malaysia: Kuala Lumpur dan Bandar-Bandar di Sekitarnya. Penang: Universiti Sains Malaysia Press.

Hassan, A. S., \& Arab, Y. (2013). The essence of design with light: Single pedentive dome mosque in Turkey and Bosnia Herzegovina during winter solstice. In S. Omer, \& A. S. Hassan, From Anatolia to Bosnia: Perspectives on Pedentive Dome Mosque Architecture. Penang: Universiti Sains Malaysia Press.

Hassan, A. S., \& Bakhlah, M. S. O. (2013). Shading Analysis on Front Facade of Modern Terraced House Type in Petaling Jaya, Malaysia. Procedia Social and Behavioural Sciences, 91, 13-27. http://dx.doi.org/ 10.1016/j.sbspro.2013.08.396

Hassan, A. S., \& K. A. Ku Hassan. (2001). Konsep Perumahan Tradisional Berkelompok dan Berdensiti Tinggi di Pantai Barat Semenanjung Malaysia (High Density Traditional Clustered Housing Concept at Western Coastal Area in Peninsular Malaysia. Penang: Universiti Sains Malaysia Press.

Hassan, A. S., \& Nawawi, M. S. A. (2014). Malay Architectural Heritage on Timber Construction Technique of the Traditional Kampung Laut Old Mosque, Malaysia. Asian Social Sciences, 10(8), $230-240$. http://dx.doi.org/ 10.5539/ass.v10n8p230

Hassan, A. S., \& Ramli, M. (2010). Natural ventilation of indoor air temperature: A case study of the Traditional Malay House in Penang. American Journal of Engineering and Applied Sciences, 3(3), 521-528. http://dx.doi.org/ 10.3844/ajeassp.2010.521.528

Ismail, A. M. (2002). Issues in tropical architecture: tall buildings, wind and ventilation. Journal of Housing, Building and Planning, 9, 63-79.

Ismail, A. M., \& Idris, M. F. (2002). Issues in tropical architecture: High-rise buildings and wind driven ventilation. Proceeding of The $2^{\text {nd }}$ Civil Engineering National Seminar, Universiti Sains Malaysia.

Khan, H. (1981). MIMAR 2: Architecture in Development. Singapore: Concept Media Ltd.

Landry, M., \& Breton, P. (2009). Daylight simulation in Autodesk 3ds Max Design 2009 - Advanced Concepts. San Rafael: Autodesk Inc.

Landry, M., \& Breton, P. (2009). Daylight simulation in Autodesk 3ds Max Design 2009-advanced concepts. Autodesk Inc.

Lim, Y. W., Ahmad, M. H., \& Ossen, D. R. (2013). Internal shading for efficient tropical daylighting in malaysian contemporary high-rise open plan office. Indoor and Built Environment, 22(6), 932-951. http://dx.doi.org/10.1016/j.buildenv.2012.04.015

Mazloomi, M., Hassan, A. S., Bagherpour, P. N., \& Ismail, M. R. (2010). Influence of Geometry and Orientation on Flank Insolation of Streets in an Arid Climate City. American Journal of Engineering and Applied Sciences, 3(3), 540-544. http://dx.doi.org/10.3844/ajeassp.2010.540.544

Olgyay, V., \& Olgyay, A. (1957). Solar Control and Shading Devices, New Jersey: Princeton University Press.

Omer, A. M. (2008). Energy, environment and sustainable development. Renew. Sustain. Energy Rev., 12(9), 2265-2300. http://dx.doi.org/ 10.1016/j.rser.2007.05.001

\section{Copyrights}

Copyright for this article is retained by the author(s), with first publication rights granted to the journal.

This is an open-access article distributed under the terms and conditions of the Creative Commons Attribution license (http://creativecommons.org/licenses/by/3.0/). 